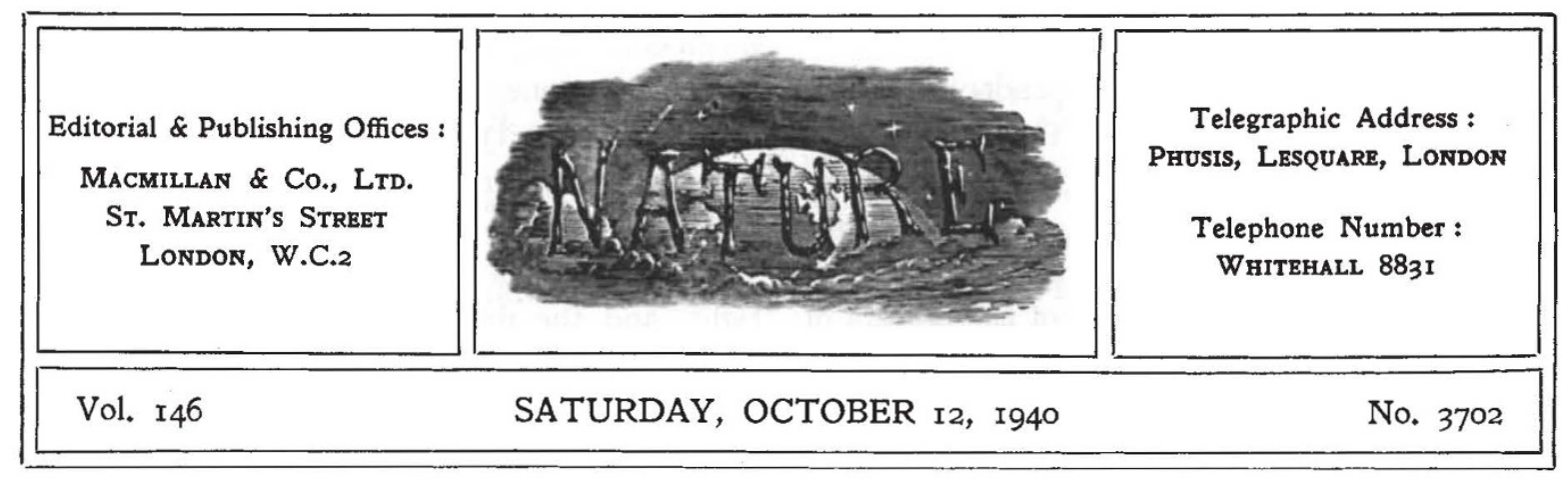

\title{
SCIENCE AND THE NATIONAL WAR EFFORT
}

$\mathrm{T}^{\mathrm{m}}$ HE recent changes in the membership of the Cabinet, coming as they did on the same day as the announcement of the appointment of a Scientific Advisory Committee responsible to the Lord President of the Council (see page 485 of this issue), will probably have overshadowed in the public mind the significance of this Committee. A scrutiny of the terms of reference, and consideration of the qualifications and standing of its members, however, will bring the realization that in this Committee we have a means of putting science into direct contact with the innermost councils of the Empire. How much this may mean for the outcome of the present conflict, and beyond that, will depend on the speed with which the Committee pursues its inquiries, the vigour with which it urges its conclusions on the Government, and a receptive mind on the part of the leaders of the country.

During the past twelve months, there has been a feeling among scientific workers, both as organized bodies and as individuals, that insufficient use was being made of their knowledge and special qualifications. Reference has frequently been made in these columns to the dissatisfaction and sense of frustration, for which the only answer hitherto has been a certain amount of lip-service to science from responsible politicians. We have been told time and time again that this is a scientific war, and that the German use of scientific developments must be met by ever more intensive application of science ; but little came of it, apart from extensive development of the scientific departments within the ministries. There seemed no realization of the need for a major step in the improvement of the organization, for the provision of a focus through which the increasing activities of scientific departments could be linked together. Sir William Bragg hinted at the prevalent anxiety in his presidential address to the Royal Society last November; and he made a definite suggestion for the constitution of a consultant panel of eminent scientific workers, that would give advice and also be kept informed of the progress of events, so that "it might foresee occasions and needs". In other words, Sir William was suggesting more than the usual committee, pursuing its investigations and making recommendations which would be forwarded to the Government through the usual departmental channels and thereby subjected to delay and, alas, often ill-informed and destructive criticism. He asked for a body with access to, and authority with, those who lay down policy.

Such a committee would, of course, have been a new departure in the system of government in which we have grown up. But evolution rather than revolution has ever been a characteristic of political history in Great Britain, and Sir William Bragg's suggestion, elaborated no doubt in association with the officers and Council of the Royal Society, was, we presume, rejected by the Government on other grounds than novelty. The scheme now adopted, although superficially it may resemble the older one, has an important difference. The members of the Committee, apart from the chairman, are indeed all fellows of the Royal Society, but three of them are in the public service, namely, the secretaries of the Department of Scientific and Industrial Research, the Medical Research Council and the Agricultural Research Council, and the other three are the president and secretaries of the Royal Society. By this means a judicious mixture of the official and unofficial is provided, and the members should be in intimate contact 
with scientific and technical developments wherever they occur.

The need for outside and independent criticism of the activities of scientific and technical departments under Government control will readily be conceded. This is no reflection on the integrity and capabilities of the many eminent men working in these departments ; it is one of the defects of the present system. Few of the political leaders of Great Britain have anything but a nodding acquaintance with science or technology, and they can get little help in this field from Civil Servants in the higher administrative posts. In consequence, the scientific and technical officers of departments become either the servants of the administrative side, with little possibility of taking a hand in the formulation of policy, or else-and more rarelytheir advice is followed blindly. Neither result is likely to be productive of the critical yet flexible and responsive attitude of mind which is required under modern conditions. Coupled with the departmental scientific advisers there should be a source of independent opinion, to the recommendations of which the minister himself may be expected to give weighty consideration.

There are in existence several such advisory councils or committees, which have fully justified the hopes entertained of them. The three research departments of the Privy Council, namely, the Department of Scientific and Industrial Research, the Medical Research Council and the Agricultural Research Council, have all worked from their formation by means of councils or committees consisting mainly of independent scientific workers, which have largely defined policy as well as administered research projects. The scientific work of the National Physical Laboratory is controlled by a body appointed by the Royal Society. The Aeronautical Research Committee, which includes many independent members, has for many years been responsible for research and development in aeronautics in Great Britain, as its many publications have shown.

To come to appointments directly concerned with warfare, there is the Committee for the Scientific Survey of Air Warfare, set up in 1935, which came to an end in June last at about the time when the Ministry of Aircraft Production was formed; this Committee was of much service to the Air Ministry, and many of the methods now used in air defence are due to its initiative. The Chemical Defence Committee, which continued for many years to advise the War Office and now the
Ministry of Supply, has a number of independent members. The Civil Defence Research Committee has done valuable work for the Ministry of Home Security. The Ministry of Supply is well served by the Council for Scientific Research and Technical Development, formed early this year, the various committees of which have the right, and the duty, of inspecting and advising upon the scientific and technical work of the establishments of the Ministry.

The Department of Scientific and Industrial Research, the Medical Research Council and the Agricultural Research Council are, of course, closely connected with the work of the Ministries of Agriculture, Health and Food, but they are responsible to the Privy Council, and their scientific councils have no direct means of ensuring that the best means for the fuller utilization of scientific and technical advice are adopted in these departments. The Fighting Services and other ministries are for the most part even less well served, so far as outside and independent critical opinion is concerned.

It is in this matter of providing opportunity for the voice of scientific men outside Government service to be heard in the deliberations of the various ministries, although not strictly within its terms of reference, that the newly appointed Scientific Advisory Committee may be able to perform a vital service. It is not a question of appointing a number of committees, ringing the changes for the several departments on the names of a few senior men of science, but rather of finding talent among the younger men, that their fresh minds may leaven those of the elders, and that their shoulders may early learn to bear the burden of responsibility.

In the conflict in which we are engaged, nothing short of the mobilization of the whole of the intellectual and material resources of the Empire will suffice. The contribution of science to the war effort should be a major one, for which the Scientific Advisory Committee may well be largely responsible. Moreover, the work must not cease with the end of the War. It does not follow that an organization which is satisfactory under the stress of modern warfare will serve equally well in times of peace ; but the principle of the immediate concern of science in formulating policy and in other ways exerting a direct and sufficient influence on the course of government is one to which we must hold fast. Science must seize the opportunity to show that it can lead mankind onward to a better form of society. 